\title{
Registered report: Melanoma genome sequencing reveals frequent PREX2 mutations
}

\author{
Denise Chroscinski ${ }^{1}$, Darryl Sampey ${ }^{2}$, Alex Hewitt ${ }^{3}$, Reproducibility Project: \\ Cancer Biology*t
}

${ }^{1}$ Noble Life Sciences, Gaithersburg, United States; ${ }^{2 B i o F a c t u r a, ~ F r e d e r i c k, ~ U n i t e d ~}$ States; ${ }^{3}$ Department of Clinical Genetics, University of Melbourne, Melbourne, Australia

\section{REPRODUCIBILITY CAROJECT- CANCER BIOLOGY}

*For correspondence: joelle@ scienceexchange.com

Group author details

${ }^{\dagger}$ Reproducibility Project:

Cancer Biology

See page 14

Competing interests: See page 14

Funding: See page 14

Received: 29 July 2014

Accepted: 11 November 2014

Published: 10 December 2014

Reviewing editor: Roger Davis, University of Massachusetts Medical School, United States

(c) Copyright Chroscinski et al. This article is distributed under the terms of the Creative Commons Attribution License, which permits unrestricted use and redistribution provided that the original author and source are credited.
Abstract The Reproducibility Project: Cancer Biology seeks to address growing concerns about reproducibility in scientific research by conducting replications of 50 papers in the field of cancer biology published between 2010 and 2012. This Registered Report describes the proposed replication plan of key experiments from 'Melanoma genome sequencing reveals frequent PREX2 mutations' by Berger and colleagues, published in Nature in 2012 (Berger et al., 2012). The key experiments that will be replicated are those reported in Figure 3B and Supplementary Figure S6. In these experiments, Berger and colleagues show that somatic PREX2 mutations identified through whole-genome sequencing of human melanoma can contribute to enhanced lethality of tumor xenografts in nude mice (Figure 3B, S6B, and S6C; Berger et alo, 2012). The Reproducibility Project: Cancer Biology is a collaboration between the Center for Open Science and Science Exchange, and the results of the replications will be published by eLife.

DOI: 10.7554/eLife.04180.001

\section{Introduction}

Melanoma is a highly aggressive tumor with poor prognosis in the metastatic stage. Based on their association with UV-induced DNA damage, melanomas are often hypermutated and considerable efforts have been made to sequence such tumors in order to better understand their molecular basis. Many well-known oncogenes are frequently involved in melanoma pathogenesis, including BRAF and NRAS, and significant work has been done to develop targeted kinase inhibitors against the protein products of these genes (Kunz, 2014). However, even with treatment, melanoma has an extremely high rate of recurrence; thus, there is great interest in identifying novel candidate genes that promote oncogenesis in melanoma, thereby providing additional therapeutic targets.

One such candidate is Phosphatidylinositol-3,4,5-trisphosphate RAC Exchanger 2 (PREX2), a 183-kDa protein known to inhibit PTEN phosphatase activity, stimulate PI3K signaling, and suspected to regulate the small GTPase RAC1 (Fine et al., 2009; Cerami et al., 2012). Using wholegenome sequencing of 25 metastatic tumors, Berger and colleagues identified PREX2 as being a highly mutated gene in melanoma. Apart from observing a large subset of BRAF and NRAS mutations, the authors found PREX2 to have a mutation frequency of approximately $14 \%$, with 13 detected non-synonymous point mutations, including four nonsense truncation mutations (Berger et al., 2012). In order to demonstrate the biological relevance of specific PREX2 mutations, the authors created transformed melanocyte cell lines that stably expressed various mutated and truncated forms of PREX2. By using these cell lines to create tumor xenografts in nude mice, the authors showed that ectopic expression of mutant PREX2 accelerated tumor formation. 
Berger and colleagues chose to analyze six representative PREX2 mutations derived from their whole-genome sequencing screen. These variants included three truncation variants and three nonsynonymous point mutations predicted to carry functional impact. These mutant PREX2 constructs were packaged into lentiviruses and transduced into TERT-immortalized human melanocytes engineered to express NRAS ${ }^{12 D}$. Ectopic expression of various mutant PREX2 isoforms was confirmed by Western blot (Figure 6A). These experiments will be replicated in Protocols 1 and 2. Berger and colleagues next transplanted the melanocytic lines into immunodeficient mice alongside control melanocytes expressing either wild-type PREX2 or GFP (green fluorescent protein). They found that overexpression of all three truncated variants, as well as the point mutation G844D, significantly accelerated tumor growth in vivo, thus affirming the biological relevance of their genomic data (Figure 3B, S6B, and S6C). These key experiments, which support the hypothesis that mutant PREX2 promotes oncogenesis in melanoma, will be replicated in Protocol 3.

There is some debate over which mutations observed in various melanoma samples are biologically relevant, including PREX2. Potentially, mutational heterogeneity across tumor samples may contribute to false-positive findings (Lawrence et al., 2013). Various genome-wide screens have yielded conflicting results about which genes are frequently mutated in melanoma. Recently, mutated PREX2 was identified in both the primary tumor and in metastatic tumor tissue from a genomic analysis of a single melanoma patient (Turajlic et al., 2012). However, five studies failed to identify PREX2 in their genome-wide melanoma screens, including a meta-analysis study that analyzed hundreds of published datasets (Hodis et al., 2012; Krauthammer et al., 2012; Ni et al., 2013; Marzese et al., 2014; Xia et al., 2014). To date, there have been no replication attempts assessing the biological significance of PREX2 mutant isoforms in melanoma.

\section{Materials and methods}

Unless otherwise noted, all protocol information was derived from the original paper, references from the original paper, or information obtained directly from the authors.

\section{Protocol 1: generation of NRAS ${ }^{\mathrm{G} 12 \mathrm{D}}$ melanocyte cells expressing various mutated forms of PREX2}

This protocol describes the generation of pMEL/hTERT/CDK4(R24C)/p53DD/NRASG12D (NRAS ${ }^{G 12 D}$ ) melanocytes that stably express various mutated forms of PREX2. This protocol details the production of lentivirus for each mutated PREX2 isoform, as well as the viral transduction of melanocytes, and selection for stable-expressing lines using antibiotic resistance.

\section{Sampling}

- Outline of experimental endpoints:

1. At the end of this protocol, we will have generated NRAS ${ }^{\mathrm{G} 12 \mathrm{D}}$ melanocytes overexpressing the following protein products:

- GFP vector (control)

- WT PREX2 (control)

- PREX2 Q1430* (Truncation mutation)

- PREX2 G844D (Substitution mutation)

\section{Materials and reagents}

\begin{tabular}{lllll} 
Reagent & Type & Manufacturer & Catalog \# & Comments \\
\hline $\begin{array}{l}\text { GenElute Endotoxin-free } \\
\text { Plasmid Maxiprep Kit }\end{array}$ & Reagent & Sigma & PLEX15-1KT & $\begin{array}{l}\text { This kit replaces the } \\
\text { Oiagen Endo-free } \\
\text { Maxiprep kit used by } \\
\text { the original authors }\end{array}$ \\
\hline pMD2-Gag/Pol & Viral packaging vector & N/A & N/A & $\begin{array}{l}\text { Reagent being } \\
\text { provided by original } \\
\text { authors }\end{array}$ \\
\hline
\end{tabular}

Table 1. Continued on next page 
Table 1. Continued

\begin{tabular}{|c|c|c|c|c|}
\hline Reagent & Type & Manufacturer & Catalog \# & Comments \\
\hline pMD2 VSVG & Viral packaging vector & N/A & N/A & $\begin{array}{l}\text { Reagent being } \\
\text { provided by original } \\
\text { authors }\end{array}$ \\
\hline RSV REV & Viral packaging vector & $\mathrm{N} / \mathrm{A}$ & N/A & $\begin{array}{l}\text { Reagent being } \\
\text { provided by original } \\
\text { authors }\end{array}$ \\
\hline GFP & Expression construct & $\mathrm{N} / \mathrm{A}$ & N/A & $\begin{array}{l}\text { Reagent being } \\
\text { provided by original } \\
\text { authors }\end{array}$ \\
\hline Wild-type PREX2 & Expression construct & $\mathrm{N} / \mathrm{A}$ & N/A & $\begin{array}{l}\text { Reagent being } \\
\text { provided by original } \\
\text { authors }\end{array}$ \\
\hline PREX2 Q1430* & Expression construct & $\mathrm{N} / \mathrm{A}$ & N/A & $\begin{array}{l}\text { Reagent being } \\
\text { provided by original } \\
\text { authors }\end{array}$ \\
\hline PREX2 G844D & Expression construct & $\mathrm{N} / \mathrm{A}$ & N/A & $\begin{array}{l}\text { Reagent being } \\
\text { provided by original } \\
\text { authors }\end{array}$ \\
\hline HEK293T cells & Cell line & ATCC & CRL-3216 & $\begin{array}{l}\text { Replaces original cells } \\
\text { from Life Technologies }\end{array}$ \\
\hline NRAS ${ }^{G 12 D}$ melanocytes & Cell line & $\mathrm{N} / \mathrm{A}$ & N/A & $\begin{array}{l}\text { Reagent being } \\
\text { provided by original } \\
\text { authors }\end{array}$ \\
\hline Sequencing primers & Oligos & \multicolumn{3}{|c|}{$\begin{array}{l}\text { Sequences provided by original authors; specific brand } \\
\text { information will be left up to the discretion of the } \\
\text { replicating lab and recorded later }\end{array}$} \\
\hline Sequencing reagents & Reagent & \multicolumn{3}{|c|}{$\begin{array}{l}\text { Specific brand information will be left up to the discretion } \\
\text { of the replicating lab and recorded later }\end{array}$} \\
\hline $\begin{array}{l}10 \mathrm{~cm} \text { tissue culture dishes } \\
\text { (plastic) }\end{array}$ & Labware & $\begin{array}{l}\text { Corning } \\
\text { (Sigma-Aldrich) }\end{array}$ & CLS430167 & $\begin{array}{l}\text { Original brand not } \\
\text { specified }\end{array}$ \\
\hline $\begin{array}{l}10 \mathrm{~cm} \text { tissue culture dishes } \\
\text { (glass) }\end{array}$ & Labware & $\begin{array}{l}\text { Corning } \\
\text { (Sigma-Aldrich) }\end{array}$ & CLS70165101 & $\begin{array}{l}\text { Additional reagent } \\
\text { not used in original } \\
\text { study }\end{array}$ \\
\hline Fetal bovine serum (FBS) & Cell culture reagent & Sigma-Aldrich & F0392 & $\begin{array}{l}\text { Replaces Invitrogen } \\
\text { cat. no. } 26400-036 \\
\text { used in original study }\end{array}$ \\
\hline $\begin{array}{l}\text { Dulbecco's Modified } \\
\text { Eagle's Medium } \\
\text { (DMEM) - high glucose }\end{array}$ & Cell culture reagent & Sigma-Aldrich & D6429 & $\begin{array}{l}\text { Replaces Invitrogen } \\
\text { cat. no. 11995-065 } \\
\text { used in original study }\end{array}$ \\
\hline Lipofectamine 2000 & Transfection reagent & Life Technologies & 52887 & \\
\hline $\begin{array}{l}\text { OptiMEM-1 reduced } \\
\text { serum medium }\end{array}$ & Cell culture reagent & Life Technologies & $31985-070$ & \\
\hline Ham's F10 medium & Cell culture reagent & Sigma-Aldrich & N6908 & $\begin{array}{l}\text { Replaces Invitrogen } \\
\text { cat. no. 11550-043 } \\
\text { used in original study }\end{array}$ \\
\hline $\begin{array}{l}\text { Fetal bovine serum } \\
\text { (FBS); heat inactivated }\end{array}$ & Cell culture reagent & Sigma-Aldrich & F4135 & $\begin{array}{l}\text { Replaces Invitrogen } \\
\text { cat. no. } 10082-147 \\
\text { used in original study }\end{array}$ \\
\hline $\begin{array}{l}\text { Penicillin-Streptomycin } \\
\text { solution (100x) stabilized }\end{array}$ & Cell culture reagent & Sigma-Aldrich & P4333 & $\begin{array}{l}\text { Replaces Invitrogen } \\
\text { cat. no. 15140-122 } \\
\text { used in original study }\end{array}$ \\
\hline $6 \mathrm{~cm}$ tissue culture dishes & Labware & $\begin{array}{l}\text { Corning } \\
\text { (Sigma-Aldrich) }\end{array}$ & CLS430166 & $\begin{array}{l}\text { Original brand not } \\
\text { specified }\end{array}$ \\
\hline $\begin{array}{l}\text { Hexadimethrine bromide } \\
\text { (Polybrene) }\end{array}$ & Cell culture reagent & Sigma-Aldrich & 107689 & $\begin{array}{l}\text { Original brand not } \\
\text { specified }\end{array}$ \\
\hline Blasticidin S, hydrochloride & Antibiotic & EMD-Millipore & 203350 & $\begin{array}{l}\text { Original brand not } \\
\text { specified }\end{array}$ \\
\hline
\end{tabular}

Table 1. Continued on next page 
Table 1. Continued

\begin{tabular}{lllll} 
Reagent & Type & Manufacturer & Catalog \# & Comments \\
\hline TRI reagent & Reagent & Sigma-Aldrich & T9424 & $\begin{array}{l}\text { Additional reagent not } \\
\text { used in original study }\end{array}$ \\
\hline $\begin{array}{l}\text { SuperScript III First-Strand } \\
\text { Synthesis System }\end{array}$ & cDNA synthesis & Life Technologies & $18080-051$ & $\begin{array}{l}\text { Additional reagent } \\
\text { not used in original } \\
\text { study }\end{array}$ \\
$\begin{array}{l}\text { Nuclease-Free Water } \\
\text { (not DEPC treated) }\end{array}$ & Reagent & Life Technologies & AM9930 & $\begin{array}{l}\text { Additional reagent } \\
\text { not used in original } \\
\text { study }\end{array}$ \\
\hline RNase AWAY (spray) & Reagent & Fisher & $21-402-178$ & $\begin{array}{l}\text { Additional reagent } \\
\text { not used in original } \\
\text { study }\end{array}$ \\
\hline
\end{tabular}

\section{Procedure}

Note: all cell lines will be sent for STR profiling and mycoplasma testing.

1. Grow and prepare endotoxin-free plasmid constructs according to the manufacturer's protocol for the GenElute Endotoxin-free Plasmid Maxiprep Kit.

A. Viral packaging vectors:

i. pMD2-Gag/Pol ( 25 $\mu \mathrm{g}$ DNA needed for production of 4 viruses)

ii. pMD2 VSVG ( $15 \mu \mathrm{g}$ DNA needed for production of 4 viruses)

iii. RSV REV ( $17 \mu \mathrm{g}$ DNA needed for production of 4 viruses)

B. PREX2 expression vectors:

i. GFP vector ( $15 \mu \mathrm{g}$ DNA needed for virus production)

ii. WT PREX2 ( $15 \mu \mathrm{g}$ DNA needed for virus production)

iii. PREX2 Q1430* ( 15 $\mu \mathrm{g}$ DNA needed for virus production)

iv. PREX2 G844D ( 15 $\mu \mathrm{g}$ DNA needed for virus production)

2. Sequence PREX2 plasmids to confirm identity and run on gel to confirm vector integrity. Use the following sequencing primers:
A. CMV forward: CGCAAATGGGCGGTAGGCGTG
B. prex2a-1 forward: ACTGAAATGCTAATGTGTGG
C. prex2a-2 forward: CCTTTTTACTCCAGTGATAAGAGAT
D. prex2a-3 forward: AGTACAGGCGGCCAACGAAG
E. prex2a-4 forward: ATCACAACCATGGCGGCCCCTT
F. prex2a-5 forward: GTAGGCTACTCCTGGCTCTT
G. prex2a-6 forward: AGCTGCCTGTGCAAACACAG
H. prex2a-7 reverse: GACTTCCTTCTGCTTGATAT
I. prex2a-8 reverse: TGCTGGTGAAGGAGGCGATG
J. prex2a-9 reverse: AGAGAATTTAGGCTGGTACA
K. prex2a-10 reverse: ATCCСТTTTCTACCAACTTT
L. prex2a-11 reverse: CTTGCTCCATTCCTAATTTT
M. prex2a-12 reverse: CCTTCTCATGGTTACTACAATATTC
N. V5 reverse: ACCGAGGAGAGGGTTAGGGAT

3. Using the same primers as above, sequence the endogenous PREX2 gene from cDNA derived from untransfected pMEL/hTERT/CDK4(R24C)/p53DD/NRAS ${ }^{\text {12D }}$ melanocytes.
A. Melanocytes should be maintained in Ham's F10 medium supplemented with $10 \%$ heat inacti- vated $\mathrm{FBS}$ and $1 \%$ penicillin/streptomycin at $37^{\circ} \mathrm{C}$ with $5 \% \mathrm{CO}_{2}$.
$B$. Isolate total RNA using TRI reagent, and generate CDNA as described in the manufacturer's pro- tocol for SuperScript III cDNA synthesis kit, using OligoDT primers to enrich for mRNA.
C. Use gene-specific primers to sequence the length of the PREX2 gene to determine endogenous mutational status. 
4. On Day 1 of viral production, plate $6 \times 10^{6}$ HEK293T cells in a $10 \mathrm{~cm}$ plate. Plate one $10-\mathrm{cm}$ plate for each virus you wish to package (total of 4 plates needed).

A. HEK293T cells should be maintained in DMEM supplemented with $10 \% \mathrm{FBS}$ at $37^{\circ} \mathrm{C}$ with $5 \% \mathrm{CO}_{2}$.

B. Note: high titer lentivirus is best packaged in early passage, healthy 293T cells. Avoid continuous growth to/from confluence. Routinely split 293T when culture approaches $80 \%$ confluence.

5. On Day 2, create the transfection master mix: (Tube \#1)

A. Create a master mix (for the number of transfections being conducted) of Lipofectamine and OptiMEM.

i. Each transfection will require $30 \mu \mathrm{l}$ of Lipofectamine diluted in $720 \mu \mathrm{l}$ of OptiMEM. Allow mixture to incubate for $5 \mathrm{~min}$ at RT.

6. For each virus, assemble DNA, packaging vectors, and OptiMEM in a $1.5 \mathrm{ml}$ centrifuge tube (Tube \#2)
A. Plasmid DNA $=10.0 \mu \mathrm{g}$
B. Packaging vector
i. $\mathrm{pMD} 2 \mathrm{Gag} / \mathrm{Pol}=5.0 \mu \mathrm{g}$
ii. $\mathrm{pRESREV}=2.5 \mu \mathrm{g}$
iii. $\mathrm{pMD} 2 \mathrm{VSVG}=3.0 \mu \mathrm{g}$

C. Bring volume to $750 \mu \mathrm{l}$ with OptiMEM.

7. Combine Tube \#1 (Lipofectamine/OptiMEM) with Tube \#2 (DNA/packaging vector/OptiMEM). After combining, mix by pipetting and allow the mixture to incubate for $20 \mathrm{~min}$ at RT.

A. While incubating, 'gently' aspirate growth medium from HEK293T cells and pipette $8 \mathrm{ml}$ of OptiMEM to each plate.

B. Add $1.5 \mathrm{ml}$ of transfection mixture to the plate (pipetting directly into the media) and place into the $37^{\circ} \mathrm{C}$ incubator.

C. Allow minimum 6-8 hr for transfection. After transfection completion, remove OptiMEM media and refresh HEK293T plates with $10 \mathrm{ml}$ of growth media (again pipetting gently onto the side of the plate).

8. On Day 4 (48 hr post-transfection) and 5 ( $72 \mathrm{hr}$ post-transfection), collect virus by removing medium and filtering through a $0.45-\mu \mathrm{m}$ filter into a $50 \mathrm{ml}$ conical tube. Pool fractions from both the days. After the two collections, there is a total of $20 \mathrm{ml}$ of virus. Immediately after collection/filtration (for both time points), put the virus on ice and then transfer to $4^{\circ} \mathrm{C}$ for short-term or $-80^{\circ} \mathrm{C}$ for longterm storage.

9. Infect pMEL/hTERT/CDK4(R24C)/p53DD/NRAS ${ }^{\mathrm{G} 12 \mathrm{D}}$ melanocytes with virus to generate stable cells lines.

A. Day 1: seed NRAS ${ }^{\mathrm{G} 12 \mathrm{D}}$ cells at $50 \%$ confluence in $6 \mathrm{~cm}$ plates.

i. Melanocytes should be maintained in Ham's F10 medium supplemented with $10 \%$ heat inactivated $\mathrm{FBS}$ and $1 \%$ penicillin/streptomycin at $37^{\circ} \mathrm{C}$ with $5 \% \mathrm{CO}_{2}$.

B. Day 2: remove media and replace with $3 \mathrm{ml}$ of viral supernatant containing $8 \mu \mathrm{g} / \mathrm{ml}$ polybrene.

i. Incubate cells for $24 \mathrm{hr}$.

C. Day 3: remove viral media and replace with fresh growth media.

D. Day 4: replace growth media with fresh media containing $5 \mu \mathrm{g} / \mathrm{ml}$ Blastocidin.

E. Days 4-9: select cells for $\sim 5$ days, confirming that a plate of non-transduced NRAS ${ }^{\mathrm{G} 12 \mathrm{D}}$ cells is negatively selected in parallel.

F. Day 9: remove Blastocidin media and expand cells into fresh growth media. Collect entire population of transduced cells for further analysis. 


\section{Deliverables}

- Data to be collected:

1. Sequencing information and gel-verification of PREX2 plasmids cloned into the pLenti6.3/V5 vector

2. Mycoplasma testing of NRAS ${ }^{G 12 D}$ melanocytes

3. STR profile of NRAS ${ }^{\mathrm{G} 12 \mathrm{D}}$ melanocytes

- Sample delivered for further analysis:

1. NRAS ${ }^{G 12 D}$ melanocytes stably expressing PREX2 mutant isoforms for further analysis (Protocols 2 and 3$)$.

\section{Confirmatory analysis plan}

- Statistical analysis of the Replication Data:

1. Not applicable.

Known differences from the original study

This replication is only generating stable melanocyte lines for GFP, wild-type PREX2, PREX2 Q1430*, and PREX2 G844D. The original study also included several other PREX2 mutants, including PREX2 K278*, E824*, P948S, and G106E. This replication will include the additional step of sequencing the endogenous PREX2 gene in the NRAS ${ }^{\mathrm{G} 12 \mathrm{D}}$ melanocyte cell line to determine its mutational status. All known differences in reagents and supplies are listed in the materials and reagents section above, with the originally used item listed in the comments section. All differences have the same capabilities as the original and are not expected to alter the experimental design.

\section{Provisions for quality control}

The cell line used in this experiment will undergo STR profiling to confirm its identity and will be sent for mycoplasma testing to ensure there is no contamination. PREX2 expression constructs obtained from the original authors will be verified for sequence identity and DNA integrity. The endogenous mutational status of PREX2 in NRAS ${ }^{\mathrm{G} 12 \mathrm{D}}$ melanocytes will be assessed. All data obtained from the experiment will be made publicly available, either in the published manuscript or as an open access dataset available on the Open Science Framework (https://osf.io/jvpnw/).

\section{Protocol 2: confirming ectopic expression of PREX2 mutant isoforms by Western blot}

This protocol investigates the expression levels of mutant PREX2 isoforms in virally transduced NRAS ${ }^{\text {G12D }}$ melanocytes that were generated in Protocol 1. This protocol uses an anti-V5 antibody to recognize tagged forms of wild-type and mutant PREX2 (as well as the GFP control), thus verifying the successful lentiviral transduction of expression constructs and providing information about ectopic protein expression levels (as was demonstrated in Figure 6A). Membranes will also be probed with anti- $\alpha$-tubulin to provide normalized values of relative protein expression. Three original cell lines produced by the original authors will also be included so that protein expression levels can be compared between the two studies.

\section{Sampling}

1. The original data presented is qualitative and this prevents power calculations being performed a priori to determine sample size (number of biological replicates). Instead, we will be including three cell lines originally derived by the authors and analyzing these cell lines in parallel to the newly derived cell lines from Protocol 1.

2. Three separate lysates will be prepared from each cell line:

- GFP vector stable NRASG12D cells (control)

- Previously generated PREX2 Q1430* stable NRASG12D cells (control from original study authors)

- Previously generated PREX2 G844D stable NRAS ${ }^{\mathrm{G} 12 \mathrm{D}}$ cells (control from original study authors) 
- Previously generated WT PREX2 stable NRASG12D cells (control from original study authors)

- PREX2 WT stable NRASG12D cells (from Protocol 1)

- PREX2 Q1430* stable NRAS ${ }^{\mathrm{G} 12 \mathrm{D}}$ cells (from Protocol 1)

- PREX2 G844D stable NRAS ${ }^{\mathrm{G} 12 \mathrm{D}}$ cells (from Protocol 1)

1. Blots will be probed with the following antibodies:
1. Anti-V5 tag
2. Anti-PREX2
3. Anti-alpha tubulin

\section{Materials and reagents}

\begin{tabular}{|c|c|c|c|c|}
\hline Reagent & Type & Manufacturer & Catalog \# & Comments \\
\hline $\begin{array}{l}\text { NRASG12D melanocytes } \\
\text { expressing GFP }\end{array}$ & Cell line & \multicolumn{2}{|l|}{ Produced in Protocol 1} & \\
\hline $\begin{array}{l}\text { NRAS }{ }^{\mathrm{G} 12 \mathrm{D}} \text { melanocytes } \\
\text { expressing WT PREX2 }\end{array}$ & Cell line & \multicolumn{2}{|l|}{ Produced in Protocol 1} & \\
\hline $\begin{array}{l}\text { NRASG12D melanocytes } \\
\text { expressing PREX2 Q1430* }\end{array}$ & Cell line & \multicolumn{2}{|l|}{ Produced in Protocol 1} & \\
\hline $\begin{array}{l}\text { NRASG12D melanocytes } \\
\text { expressing G844D }\end{array}$ & Cell line & \multicolumn{2}{|l|}{ Produced in Protocol 1} & \\
\hline $\begin{array}{l}\text { NRASG12D melanocytes } \\
\text { expressing WT PREX2 }\end{array}$ & Cell line & \multicolumn{2}{|c|}{ Obtained from original authors } & \\
\hline $\begin{array}{l}\text { NRAS }{ }^{\mathrm{G} 12 \mathrm{D}} \text { melanocytes } \\
\text { expressing PREX2 Q1430* }\end{array}$ & Cell line & \multicolumn{2}{|c|}{ Obtained from original authors } & \\
\hline $\begin{array}{l}\text { NRASG12D melanocytes } \\
\text { expressing G844D }\end{array}$ & Cell line & \multicolumn{2}{|c|}{ Obtained from original authors } & \\
\hline Ham's F10 medium & Cell culture reagent & Sigma-Aldrich & N6908 & $\begin{array}{l}\text { Replaces Invitrogen } \\
\text { cat. no. } 11550-043 \\
\text { used in original study }\end{array}$ \\
\hline $\begin{array}{l}\text { Fetal bovine serum (FBS); } \\
\text { heat inactivated }\end{array}$ & Cell culture reagent & Sigma-Aldrich & F4135 & $\begin{array}{l}\text { Replaces Invitrogen } \\
\text { cat. no. } 10082-147 \\
\text { used in original study }\end{array}$ \\
\hline $\begin{array}{l}\text { Penicillin-streptomycin } \\
\text { solution (100x) stabilized }\end{array}$ & Cell culture reagent & Sigma-Aldrich & P4333 & $\begin{array}{l}\text { Replaces Invitrogen } \\
\text { cat. no. } 15140-122 \\
\text { used in original study }\end{array}$ \\
\hline $\begin{array}{l}\text { IGEPAL CA-630 } \\
\text { (NP-40 substitute) }\end{array}$ & Reagent & Sigma-Aldrich & 18896 & $\begin{array}{l}\text { Replaces US Biological } \\
\text { cat. no. N3500 used in } \\
\text { original study }\end{array}$ \\
\hline $\begin{array}{l}\text { Phenylmethanesulfonyl } \\
\text { fluoride (PMSF) }\end{array}$ & Reagent & Sigma-Aldrich & 78,830 & $\begin{array}{l}\text { Replaces Pierce cat. } \\
\text { no. } 36978 \text { used in } \\
\text { original study }\end{array}$ \\
\hline $\begin{array}{l}\text { Protease inhibitor } \\
\text { cocktail (mammalian) }\end{array}$ & Reagent & Sigma-Aldrich & P8340 & $\begin{array}{l}\text { Replaces Roche cat. } \\
\text { no. } 11836153001 \text { used } \\
\text { in original study }\end{array}$ \\
\hline $\begin{array}{l}\text { Phosphatase inhibitor } \\
\text { cocktail } 2\end{array}$ & Reagent & Sigma-Aldrich & P5726 & $\begin{array}{l}\text { Replaces Roche cat. } \\
\text { no. } 04906837001 \text { used } \\
\text { in original study }\end{array}$ \\
\hline $\begin{array}{l}\text { Coomassie (Bradford) } \\
\text { Protein Assay Kit }\end{array}$ & Reagent & Thermo-Fisher (Pierce) & PI-23200 & $\begin{array}{l}\text { Original brand not } \\
\text { specified }\end{array}$ \\
\hline BCA Protein Assay Kit & Reagent & Thermo-Fisher (Pierce) & 23227 & $\begin{array}{l}\text { Original brand not } \\
\text { specified }\end{array}$ \\
\hline 10-cm tissue culture dishes & Labware & $\begin{array}{l}\text { Corning } \\
\text { (Sigma-Aldrich) }\end{array}$ & CLS430167 & $\begin{array}{l}\text { Original brand not } \\
\text { specified }\end{array}$ \\
\hline $\begin{array}{l}\text { Novex 4-12\% Tris-Glycine, } \\
\text { Mini, } 1.0 \text { mm, 12-well }\end{array}$ & Reagent & Life Technologies & EC60352 & \\
\hline
\end{tabular}

Table 2. Continued on next page 
Table 2. Continued

\begin{tabular}{|c|c|c|c|c|}
\hline Reagent & Type & Manufacturer & Catalog \# & Comments \\
\hline $\begin{array}{l}\text { Novex Tris-Glycine SDS } \\
\text { Running Buffer (10X) }\end{array}$ & Reagent & Life Technologies & LC2675 & $\begin{array}{l}\text { Original brand not } \\
\text { specified }\end{array}$ \\
\hline $\begin{array}{l}\text { Novex Tris-Glycine SDS } \\
\text { Sample Buffer (2X) }\end{array}$ & Reagent & Life Technologies & LC2676 & $\begin{array}{l}\text { Original brand not } \\
\text { specified }\end{array}$ \\
\hline $\begin{array}{l}\text { NuPAGE }{ }^{\circledR} \text { Sample } \\
\text { Reducing Agent (10X) }\end{array}$ & Reagent & Life Technologies & NP0009 & $\begin{array}{l}\text { Original brand not } \\
\text { specified }\end{array}$ \\
\hline $\begin{array}{l}\text { ECL DualVue Western } \\
\text { Markers ( } 15 \text { to } 150 \mathrm{kDa} \text { ) }\end{array}$ & Reagent & Sigma-Aldrich & GERPN810 & $\begin{array}{l}\text { Original brand not } \\
\text { specified }\end{array}$ \\
\hline $\begin{array}{l}\text { BLUEeye prestained } \\
\text { protein ladder }\end{array}$ & Reagent & Sigma-Aldrich & 94964 & $\begin{array}{l}\text { Original brand not } \\
\text { specified }\end{array}$ \\
\hline Nitrocellulose membrane & Reagent & BioRad & $162-0113$ & $\begin{array}{l}\text { Original brand not } \\
\text { specified }\end{array}$ \\
\hline Ponceau S solution & Reagent & Sigma-Aldrich & P7170 & $\begin{array}{l}\text { Original brand not } \\
\text { specified }\end{array}$ \\
\hline Mouse anti-V5 tag & Antibody & Invitrogen & 451098 & \\
\hline $\begin{array}{l}\text { Mouse anti-a-tubulin, } \\
\text { clone DM1A }\end{array}$ & Antibody & Sigma-Aldrich & T9026 & \\
\hline Mouse anti-PREX2 & Antibody & Abcam & Ab169027 & $\begin{array}{l}\text { Additional reagent } \\
\text { not used in original } \\
\text { study }\end{array}$ \\
\hline $\begin{array}{l}\text { Horse anti-mouse IgG, } \\
\text { HRP-linked antibody }\end{array}$ & Antibody & $\begin{array}{l}\text { Cell Signaling } \\
\text { Technologies (CST) }\end{array}$ & 7076 & \\
\hline Tris Buffered Saline (TBS) & Reagent & Sigma-Aldrich & T5912 & $\begin{array}{l}\text { Replaces Fisher cat. } \\
\text { no. BP2471-1 used } \\
\text { in original study }\end{array}$ \\
\hline Tween 20 & Reagent & Sigma-Aldrich & P1379 & $\begin{array}{l}\text { Original brand not } \\
\text { specified }\end{array}$ \\
\hline $\begin{array}{l}\text { ECL Prime Western Blotting } \\
\text { Detection Reagent }\end{array}$ & Reagent & $\begin{array}{l}\text { Sigma-Aldrich } \\
\text { (GE Healthcare) }\end{array}$ & GERPN2236 & $\begin{array}{l}\text { Replaces Pierce cat. } \\
\text { no. } 34075 \text { used in } \\
\text { original study }\end{array}$ \\
\hline
\end{tabular}

\section{Procedure}

1. Maintain NRAS ${ }^{\mathrm{G} 12 \mathrm{D}}$ melanocyte lines in Ham's $\mathrm{F} 10$ medium with $10 \%$ heat inactivated $\mathrm{FBS}$ and $1 \%$ penicillin/streptomycin at $37^{\circ} \mathrm{C}$ with $5 \% \mathrm{CO}_{2}$.

2. Subculture the four cell lines onto three $10-\mathrm{cm}$ plates each, for a total of 12 plates. These plates constitute replicates for each cell line for eventual quantitation of protein expression. Allow cells to grow to log phase.

3. Place $10 \mathrm{~cm}$ plates of log-phase growing cells on ice. Use a cell-scraper to scrape cells (on ice) into a microcentrifuge tube. Add $250 \mu$ l of lysis buffer per $10 \mathrm{~cm}$ plate.

A. Lysis buffer = 20 mM Tris- $\mathrm{HCl}$, pH 8.0, 150 mM NaCl, 2 mM EDTA, 1\% NP40, 1 mM PMSF, $1 \times$ protease inhibitor cocktail, and $1 \times$ phosphatase inhibitor.

B. Prepare three separate lysates for each cell line (one lysate scraped from each plate).

4. Incubate cells in lysis buffer for $20 \mathrm{~min}$ at RT. Centrifuge lysate for $15 \mathrm{~min}$ at $14,000 \mathrm{rpm}$ at $4^{\circ} \mathrm{C}$. Transfer supernatant to a fresh tube, then add $2 \times$ sample loading buffer containing reducing agent.

5. Load lysate onto a pre-cast polyacrylamide 4-12\% Tris-glycine gel with molecular weight ladder.

A. Quantify lysate total protein concentration.

B. Load $30-50 \mu \mathrm{g}$ of total protein per well.

6. Perform electrophoresis in standard Tris-glycine-SDS running buffer.

7. Transfer the gel onto a nitrocellulose membrane.

A. Transfer buffer = $25 \mathrm{mM}$ Tris- $\mathrm{HCl}, 192 \mathrm{mM}$ glycine, $20 \%$ methanol. 
B. Use standard wet-transfer for 1-2 hr; PREX2 is a relatively large protein (runs about $160 \mathrm{kDa}$ ).

C. Following protein transfer, stain the membrane with Ponceau-S in order to detect protein levels. Scan image of stained membrane before washing.

8. Block membrane in $5 \%$ milk in $1 \times$ TBS with $0.1 \%$ Tween-20 (TBS-T) overnight at $4^{\circ} \mathrm{C}$ on an orbital shaker.

9. Incubate membranes with primary antibody overnight at $4^{\circ} \mathrm{C}$ on an orbital shaker. Dilute primary antibodies in $5 \%$ bovine serum albumin in TBS-T containing $0.05 \%$ sodium azide.

A. Mouse anti-V5; dilute at 1:5000.

B. Mouse anti-PREX2; use at $1 \mu \mathrm{g} / \mathrm{ml}$, according to the manufacturer's instructions.

10. Wash membranes six times for 10 min each with TBS-T at room temperature (RT).

11. Incubate membranes with secondary antibody for $40 \mathrm{~min}$ at RT on an orbital shaker. Dilute secondary antibody in $5 \%$ milk in TBS-T.

A. Horse anti-mouse IgG; dilute at 1:2000

12. Wash membranes six times for 10 min each with TBS-T at RT.

13. Detect chemiluminescent signal with ECL Prime Western blotting detection reagent, according to the manufacturer's instructions.

14. Strip blots for $15 \mathrm{~min}$ in $0.2 \mathrm{M} \mathrm{NaOH}$, then wash membranes six times for 10 min each with TBS-T at RT.

15. Block membranes in $5 \%$ milk in TBS-T for $1 \mathrm{hr}$ at RT on an orbital shaker.

16. Repeat steps 9-13 for anti-a-tubulin primary antibody. Dilute primary antibody at 1:5000. Use same secondary antibody (at same dilution) as above.

17. Quantify density of bands and normalize against $\alpha$-tubulin.

\section{Deliverables}

- Data to be collected:

1. Images of probed membranes (full images with ladder)

2. Scanned images of Ponceau-stained membranes, post-transfer

3. Densitometric analyses of normalized bands, presented in a bar graph showing standard deviation across replicates for each cell line

\section{Confirmatory analysis plan}

- Statistical analysis of the Replication Data:

1. Means and standard deviations will be computed across replicates for each cell line.

2. We will perform a 2-way ANOVA ( $2 \times 3$ factorial analysis), comparing expression levels of the three PREX2 variants and the two cell-line cohorts (the originally-derived cell lines and the newly-derived cell lines from Protocol 1). This analysis will test two parameters: a) whether the original and replication values are different and b) if the three PREX2 variants are different. Because our hypothesis is that they are all the same, no individual follow-up tests are needed.

\section{Known differences from the original study}

This replication is only analyzing protein expression from cell lines engineered to express GFP, wildtype PREX2, PREX2 Q1430*, and PREX2 G844D. The original study also included several other PREX2 mutants, including PREX2 K278*, E824*, P948S, and G106E. This replication includes an antibody probing for PREX2, so that we can better determine its endogenous expression level. Additionally, we are also testing protein expression in the original PREX2 cells lines derived by the original authors, so that we can compare expression levels between the original lines and the replication lines. All known differences in reagents and supplies are listed in the materials and reagents section above, with the originally used item listed in the comments section. All differences have the same capabilities as the original and are not expected to alter the experimental design. 
Provisions for quality control

The endogenous expression of PREX2 will be assessed in cell lines not overexpressing PREX2 variants. An image of Ponceau-stained membranes (post-transfer) will be included to verify successful protein transfer. All of the raw data, including the image files and quantified bands from the Western blot, will be uploaded to the project page on the OSF (https://osf.io/jvpnw/) and made publically available. This experiment is also the quality control for the other replication protocols as it assesses the levels of ectopic PREX2 variant expression in the utilized cell lines.

\section{Protocol 3: generation of tumor xenografts expressing mutated forms of PREX2}

This protocol assesses the propensity of ectopically expressed PREX2 mutations to accelerate tumor formation of immortalized human melanocytes in vivo. This protocol utilizes stably transfected NRAS ${ }^{612 D}$ human melanocyte lines that were previously generated and analyzed in Protocols 1 and 2. The melanocytic lines are transplanted into immunodeficient mice alongside control melanocytes expressing wild-type PREX2 or GFP (green fluorescent protein). Tumor growth is assessed for 16 weeks, and tumor-free survival is monitored, as depicted in Figure 3B, S6B. Further, confirmatory staining and analysis of tumor tissue will be completed, as depicted in Figure 6C.

Sampling

- These experiments will utilize 7,8 , or 14 mice per treatment group, for a total power of $\geq 80 \%$.

1. See Power calculations section for details

- Outline of experimental conditions:

1. NCR-NUDE female mice injected subcutaneously with:

- GFP-vector stable NRAS ${ }^{\mathrm{G} 12 \mathrm{D}}$ melanocytes (control)

$\circ n=14$

- PREX2 WT stable NRAS ${ }^{\mathrm{G} 12 \mathrm{D}}$ melanocytes (control)

$\circ \mathrm{n}=7$

- PREX2 Q1430* NRAS ${ }^{\mathrm{G} 12 \mathrm{D}}$ melanocytes

$\circ \mathrm{n}=8$

- PREX2 G844D NRAS ${ }^{G 12 D}$ melanocytes

$\circ n=14$

\section{Materials and reagents}

\begin{tabular}{|c|c|c|c|c|}
\hline Reagent & Type & Manufacturer & Catalog \# & Comments \\
\hline $\begin{array}{l}\text { NRAS }^{\mathrm{G} 12 \mathrm{D}} \text { melanocytes } \\
\text { expressing GFP }\end{array}$ & Cell line & \multicolumn{3}{|c|}{ Produced in Protocol 1} \\
\hline $\begin{array}{l}\text { NRAS }{ }^{G 12 D} \text { melanocytes } \\
\text { expressing WT PREX2 }\end{array}$ & Cell line & \multicolumn{3}{|c|}{ Produced in Protocol 1} \\
\hline $\begin{array}{l}\text { NRAS }{ }^{G 12 D} \text { melanocytes } \\
\text { expressing PREX2 Q1430* }\end{array}$ & Cell line & \multicolumn{3}{|c|}{ Produced in Protocol 1} \\
\hline $\begin{array}{l}\text { NRAS }{ }^{\mathrm{G} 12 \mathrm{D}} \text { melanocytes } \\
\text { expressing G844D }\end{array}$ & Cell line & \multicolumn{3}{|c|}{ Produced in Protocol 1} \\
\hline Ham's F10 medium & Cell culture reagent & Sigma-Aldrich & N6908 & $\begin{array}{l}\text { Replaces Invitrogen } \\
\text { cat. no. 11550-043 } \\
\text { used in original } \\
\text { study }\end{array}$ \\
\hline
\end{tabular}

Table 3. Continued on next page 
Table 3. Continued

\begin{tabular}{|c|c|c|c|c|}
\hline Reagent & Type & Manufacturer & Catalog \# & Comments \\
\hline $\begin{array}{l}\text { Hanks' balanced salt } \\
\text { solution, with sodium } \\
\text { bicarbonate, } \\
\text { without phenol red, } \\
\text { calcium chloride, and } \\
\text { magnesium sulfate }\end{array}$ & Cell culture reagent & Sigma-Aldrich & H6648 & $\begin{array}{l}\text { Original brand } \\
\text { not specified }\end{array}$ \\
\hline $\begin{array}{l}\text { Matrigel Matrix High } \\
\text { Concentration }(H C) \text {, } \\
\text { phenol red-free }\end{array}$ & Cell culture reagent & Corning & 354262 & $\begin{array}{l}\text { Original catalog } \\
\text { number not } \\
\text { specified }\end{array}$ \\
\hline $\begin{array}{l}\text { Fetal bovine serum (FBS); } \\
\text { heat inactivated }\end{array}$ & Cell culture reagent & Sigma-Aldrich & F4135 & $\begin{array}{l}\text { Replaces Invitrogen } \\
\text { cat. no. 10082-147 } \\
\text { used in original } \\
\text { study }\end{array}$ \\
\hline $\begin{array}{l}\text { Penicillin-streptomycin } \\
\text { solution }(100 x) \text { stabilized }\end{array}$ & Cell culture reagent & Sigma-Aldrich & P4333 & $\begin{array}{l}\text { Replaces Invitrogen } \\
\text { cat. no. 15140-122 } \\
\text { used in original } \\
\text { study }\end{array}$ \\
\hline $\begin{array}{l}1 \mathrm{~mL} \text { syringe; } 26 \mathrm{G} \times 5 / 8 \\
\text { needle (single-use) }\end{array}$ & Labware & BD Biosciences & 309597 & $\begin{array}{l}\text { Original brand not } \\
\text { specified }\end{array}$ \\
\hline $\begin{array}{l}\text { NCR-NUDE mice(homozygous; } \\
\text { NCRNU-F) }\end{array}$ & Mouse line & Taconic & NCRNU-F & \\
\hline Carazzi's Haematoxylin & IHC Stain & \multirow{3}{*}{\multicolumn{3}{|c|}{$\begin{array}{l}\text { Specific brand information will be left up to the } \\
\text { discretion of the replicating lab and recorded later }\end{array}$}} \\
\hline Eosin & IHC Stain & & & \\
\hline Permount & Mounting medium & & & \\
\hline
\end{tabular}

\section{Procedure}

1. Maintain NRAS ${ }^{\mathrm{G} 12 \mathrm{D}}$ cell lines in Ham's $\mathrm{F} 10$ medium with $10 \%$ heat inactivated FBS and $1 \%$ penicillin/ streptomycin at $37^{\circ} \mathrm{C}$ with $5 \% \mathrm{CO}_{2}$.

2. Resuspend $1 \times 10^{6}$ cells in a 1:1 ratio of Matrigel and Hanks' balanced salt solution and keep on ice. The final injection volume should be $100 \mu \mathrm{l}$.

3. Subcutaneously inject $1 \times 10^{6}$ cells with a 26 -gauge needle and insulin syringe into 6- to 8-week old female NCR-NUDE mice.
A. Mice were housed per IACUC regulations, in barrier housing with standard chow and $12 \mathrm{hr}$ light/ dark cycles.
B. Anesthetize mice with isofluorane prior to injection.
C. Inject mice subcutaneously on the flank.

4. Monitor mice three times a week for tumor development for 16 weeks.
A. Record date when visible tumor is detected.

5. Measure tumor volume once weekly.

A. Measure tumor in two directions with calipers. Calculate tumor volume as (length $\times$ width $\left.{ }^{2}\right) / 2$.

6. Track survival of mice for 16 weeks, recording dates of euthanasia.
A. Sacrifice mice when tumor volume reaches $1.5 \mathrm{~cm}^{3}$ or if mice become moribund or cachectic.
B. Sacrifice any surviving mice at the end of the study.

7. Upon euthanasia, harvest and process tumor tissue for further analysis.
A. Harvest one representative tumor per mouse group (total of 4 tumors).
B. Fix tissues in $10 \%$ neutral buffered formalin for $24 \mathrm{hr}$.
C. Dehydrate tissues through graded alcohols and clear in xylene.
D. Infiltrate with, and then embed, tissues in paraffin and section into 5- $\mu$ m sections.
E. Mount sections onto positively charged slides. 
8. Stain tumor section with $\mathrm{H} \& \mathrm{E}$ (total: 1 stained section per tumor $=4$ stained sections).

A. Perform H\&E staining by hand using the following procedure:

i. Deparaffinize sections twice in xylene, then rehydrate through graded alcohols $(95 \%, 70 \%$, $50 \% \mathrm{ETOH}$ ) to water.

ii. Stain sections with Carazzi's hematoxylin, then rinse slides in water.

iii. Stain sections with eosin.

iv. Dehydrate sections through graded alcohols $(50 \%, 70 \%, 90 \%)$ and then place in xylene.

$v$. Apply coverslips to slides with Permount and store slides at room temperature.

9. Blindly image stained sections and have images blindly analyzed by a Board Certified Veterinary Pathologist to verify the tumor composition of the tissue sections.

\section{Data to be collected}

- Deliverables:

1. Mouse health records (age, time to tumor detection, tumor incidence, date of euthanasia, and cause of termination)

2. Raw and calculated tumor volume measurements for each date/mouse

3. Kaplan-Meier curves generated for tumor-free survival of each mouse line

4. Images of H\&E stained tumor sections and pathology report. (compare to Figure 6C)

5. Pathologist's report of tissue section evaluation

\section{Confirmatory analysis plan}

This replication attempt will perform the statistical analyses listed below, compute the effects sizes, compare them against the reported effect size in the original paper, and use a meta-analytic approach to combine the original and replication effects, which will be presented as a Forest plot.

- Statistical analysis of the Replication Data:

1. Comparison of Kaplan-Meier survival curves tracking tumor incidence using Bonferroni's correction for multiple comparisons.

- The authors originally examined the Kaplan-Meier curves for PREX2 mutants and compared the endpoint values of the mutant curves to the endpoint values of the wild-type PREX2 curve using an unpaired two-tailed $t$-test. We will replicate their $t$-tests but also compare the entire survival curves (each mutant curve vs both wild-type and GFP control) using the log-rank Mantel-Cox test with Bonferroni's alpha correction, which we believe is a more appropriate statistical approach.

2. Comparison of tumor growth rates

- We will measure tumor growth rates across all mouse cohorts over the length of the study. These data were collected but not reported or analyzed in the original study. We will plot growth curves for each treatment group and use area under the curve analysis to calculate the mean and std. error. We will then use the means, std. error, and $n$ to perform a 1-way ANOVA. Further, we will perform corrected $t$-tests (Bonferroni correction) to perform pairwise comparisons between PREX2 mutants and either GFP or wild-type controls.

\section{Known differences from the original study}

This replication is only generating and analyzing xenografts based on the stable melanocyte lines for GFP, wild-type PREX2, PREX2 Q1430*, and PREX2 G844D. The original study also generated and analyzed tumor xenografts using other PREX2 mutant-expressing melanocyte lines, including PREX2 $\mathrm{K} 278^{*}$, E824*, P948S, and G106E. In order to sufficiently power all experiments and achieve the necessary number of events for Kaplan-Meier analysis, the duration of this replication will be extended from 9 weeks in the original paper to 16 weeks in the replication. All known differences in reagents and supplies are listed in the materials and reagents section above, with the originally used item listed in 
the comments section. All differences have the same capabilities as the original and are not expected to alter the experimental design.

Provisions for quality control

The genetic integrity, mycoplasma-free purity, and levels of exogenous expression of each NrasG12V melanocyte line used in this experiment have been previously validated in Protocols 1 and 2. All mice will be handled and housed in accordance with the Institutional Animal Care and Use Committee (IACUC). All data obtained from the experiment-raw data, data analysis, control data, and quality control data-will be made publicly available, either in the published manuscript or as an open access dataset available on the Open Science Framework (https://osf.io/82nfe/)

\section{Power calculations}

\section{Protocol 3}

\section{Summary of original data}

Figure 3B. Kaplan-Meier

\begin{tabular}{lllll} 
survival curves & Median survival & Hazards ratio [to WT] & Hazards ratio [to GFP] & N \\
\hline WT PREX2 & N/A & N/A & N/A & 10 \\
\hline GFP & N/A & N/A & N/A & 10 \\
\hline PREX2 Q1430* & 5 weeks & 0.08758 & 0.1243 & 10 \\
\hline PREX2 G844D & 5 weeks & 0.1296 & 0.1952 & 10
\end{tabular}

Note: Mantel-Haenszel hazard ratios were generated in Graphpad Prism v. 6.0 following analysis of Kaplan-Meier curves with the log-rank (Mantel-Cox) test using the Mantel-Haenszel method.

\section{Test family}

- Log-rank (Mantel-Cox) test with Bonferroni alpha correction for multiple comparisons

\section{Power calculations}

- Performed with the Sample Size Calculator hosted by the Clinical \& Translational Science Institute (CTSI) at the University of California-San Francisco (http://www.sample-size.net/sample-size-survivalanalysis/) (Rubinstein et al., 1981; Schoenfeld, 1983)

- To account for multiple comparisons, a corrected alpha value of $0.0125[0.05 / 4]$ was used in determining power calculations.

\begin{tabular}{|c|c|c|c|c|c|c|}
\hline & $\begin{array}{l}\text { Experiment } \\
\text { duration }\end{array}$ & $\begin{array}{l}\text { A Priori } \\
\text { power }\end{array}$ & $\begin{array}{l}\text { Total events } \\
\text { needed (WT } \\
\text { or GFP) }\end{array}$ & $\begin{array}{l}\text { Estimated } \\
\text { sample size } \\
\text { (WT or GFP) }\end{array}$ & $\begin{array}{l}\text { Total events } \\
\text { needed } \\
\text { (PREX2 } \\
\text { mutants) }\end{array}$ & $\begin{array}{l}\text { Estimated } \\
\text { sample size } \\
\text { (PREX2 } \\
\text { mutant) }\end{array}$ \\
\hline Q1430* vs WT & 16 weeks & $\geq 80 \%$ & 1 & 7 & 6 & 7 \\
\hline G844D vs WT & 16 weeks & $\geq 80 \%$ & 1 & 6 & 11 & 12 \\
\hline Q1430* vs GFP & 16 weeks & $\geq 80 \%$ & 3 & 14 & 7 & 8 \\
\hline G844D vs GFP & 16 weeks & $\geq 80 \%$ & 4 & 14 & 12 & 14 \\
\hline
\end{tabular}

\section{Acknowledgements}

The Reproducibility Project: Cancer Biology core team would like to thank the original authors, in particular Levi Garraway, Lynda Chin, and most especially Yonathan Lissanu Deribe, for generously sharing critical information as well as reagents to ensure the fidelity and quality of this replication attempt. We are grateful to Courtney Soderberg at the Center for Open Science for assistance with statistical analyses. We would also like to thank the following companies for generously donating reagents to the Reproducibility Project: Cancer Biology: American Type Culture Collection (ATCC), BioLegend, Charles River Laboratories, Corning Incorporated, DDC Medical, EMD Millipore, Harlan Laboratories, LI-COR Biosciences, Mirus Bio, Novus Biologicals, and Sigma-Aldrich. 


\section{Additional information}

Group author details

\section{Reproducibility Project: Cancer Biology}

Elizabeth lorns: Science Exchange, Palo Alto, California; William Gunn: Mendeley, London, United Kingdom; Fraser Tan: Science Exchange, Palo Alto, United States; Joelle Lomax: Science Exchange, Palo Alto, United States; Timothy Errington: Center for Open Science, Charlottesville, United States

Competing interests

DC: Noble Life Sciences is a Science Exchange associated lab. DS: BioFactura is a Science Exchange associated lab. RP:CB: El, FT and JL are employed by, and holds shares in, Science Exchange, Inc. The other authors declare that no competing interests exist.

Funding

\begin{tabular}{ll} 
Funder & Author \\
\hline Laura and John Arnold Foundation & Reproducibility Project: Cancer Biology
\end{tabular}

The Reproducibility Project: Cancer Biology is funded by the Laura and John Arnold Foundation, provided to the Center for Open Science in collaboration with Science Exchange. The funder had no role in study design or the decision to submit the work for publication.

Author contributions

DC, DS, Conception and design; AH, Drafting or revising the article; RP:CB, Conception and design, Drafting or revising the article

\section{References}

Berger MF, Hodis E, Heffernan TP, Deribe YL, Lawrence MS, Protopopov A, Ivanova E, Watson IR, Nickerson E, Ghosh P, Zhang H, Zeid R, Ren X, Cibulskis K, Sivachenko AY, Wagle N, Sucker A, Sougnez C, Onofrio R, Ambrogio L, Auclair D, Fennell T, Carter SL, Drier Y, Stojanov P, Singer MA, Voet D, Jing R, Saksena G, Barretina J, Ramos AH, Pugh TJ, Stransky N, Parkin M, Winckler W, Mahan S, Ardlie K, Baldwin J, Wargo J, Schadendorf D, Meyerson M, Gabriel SB, Golub TR, Wagner SN, Lander ES, Getz G, Chin L, Garraway LA. 2012. Melanoma genome sequencing reveals frequent PREX2 mutations. Nature 485:502-506. doi: 10.1038/nature11071.

Cerami E, Gao J, Dogrusoz U, Gross BE, Sumer SO, Aksoy BA, Jacobsen A, Byrne CJ, Heuer ML, Larsson E, Antipin Y, Reva B, Goldberg AP, Sander C, Schultz N. 2012. The cBio cancer genomics portal: an open platform for exploring multidimensional cancer genomics data. Cancer Discovery 2:401-404. doi: 10.1158/2159-8290.CD-12-0095.

Fine B, Hodakoski C, Koujak S, Su T, Saal LH, Maurer M, Hopkins B, Keniry M, Sulis ML, Mense S, Hibshoosh H, Parsons R. 2009. Activation of the PI3K pathway in cancer through inhibition of PTEN by exchange factor P-REX2a. Science 325:1261-1265. doi: 10.1126/science.1173569.

Hodis E, Watson IR, Kryukov GV, Arold ST, Imielinski M, Theurillat JP, Nickerson E, Auclair D, Li L, Place C, Dicara D, Ramos AH, Lawrence MS, Cibulskis K, Sivachenko A, Voet D, Saksena G, Stransky N, Onofrio RC, Winckler W, Ardlie K, Wagle N, Wargo J, Chong K, Morton DL, Stemke-Hale K, Chen G, Noble M, Meyerson M, Ladbury JE, Davies MA, Gershenwald JE, Wagner SN, Hoon DS, Schadendorf D, Lander ES, Gabriel SB, Getz G, Garraway LA, Chin L. 2012. A landscape of driver mutations in melanoma. Cell 150:251-263. doi: 10.1016/j. cell.2012.06.024.

Krauthammer M, Kong Y, Ha BH, Evans P, Bacchiocchi A, McCusker JP, Cheng E, Davis MJ, Goh G, Choi M, Ariyan S, Narayan D, Dutton-Regester K, Capatana A, Holman EC, Bosenberg M, Sznol M, Kluger HM, Brash DE, Stern DF, Materin MA, Lo RS, Mane S, Ma S, Kidd KK, Hayward NK, Lifton RP, Schlessinger J, Boggon TJ, Halaban R. 2012. Exome sequencing identifies recurrent somatic RAC1 mutations in melanoma. Nature Genetics 44:1006-1014. doi: 10.1038/ng.2359.

Kunz M. 2014. Oncogenes in melanoma: an update. European Journal of Cell Biology 93:1-10. doi: 10.1016/j. ejcb.2013.12.002.

Lawrence MS, Stojanov P, Polak P, Kryukov GV, Cibulskis K, Sivachenko A, Carter SL, Stewart C, Mermel CH, Roberts SA, Kiezun A, Hammerman PS, McKenna A, Drier Y, Zou L, Ramos AH, Pugh TJ, Stransky N, Helman E, Kim J, Sougnez C, Ambrogio L, Nickerson E, Shefler E, Cortes ML, Auclair D, Saksena G, Voet D, Noble M, DiCara D, Lin P, Lichtenstein L, Heiman DI, Fennell T, Imielinski M, Hernandez B, Hodis E, Baca S, Dulak AM, Lohr J, Landau DA, Wu CJ, Melendez-Zajgla J, Hidalgo-Miranda A, Koren A, McCarroll SA, Mora J, Lee RS, Crompton B, Onofrio R, Parkin M, Winckler W, Ardlie K, Gabriel SB, Roberts CW, Biegel JA, Stegmaier K, Bass AJ, Garraway LA, Meyerson M, Golub TR, Gordenin DA, Sunyaev S, Lander ES, Getz G. 2013. Mutational heterogeneity in cancer and the search for new cancer-associated genes. Nature 499:214-218. doi: 10.1038/ nature12213. 
Marzese DM, Scolyer RA, Roque M, Vargas-Roig LM, Huynh JL, Wilmott JS, Murali R, Buckland ME, Barkhoudarian G, Thompson JF, Morton DL, Kelly DF, Hoon DS. 2014. DNA methylation and gene deletion analysis of brain metastases in melanoma patients identifies mutually exclusive molecular alterations. Neuro Oncology 16:1499-1509. doi: 10.1093/neuonc/nou107.

Ni TK, Landrette SF, Bjornson RD, Bosenberg MW, Xu T. 2013. Low-copy piggyBac transposon mutagenesis in mice identifies genes driving melanoma. Proceedings of the National Academy of Sciences of USA 110: E3640-E3649. doi: 10.1073/pnas.1314435110.

Rubinstein LV, Gail MH, Santner TJ. 1981. Planning the duration of a comparative clinical trial with loss to follow-up and a period of continued observation. Journal of Clinical Epidemiology 34:469-479. doi: 10.1016/ 0021-9681(81)90007-2.

Schoenfeld DA. 1983. Sample-size formula for the proportional-hazards regression model. Biometrics 39: 499-503. doi: 10.2307/2531021.

Turajlic S, Furney SJ, Lambros MB, Mitsopoulos C, Kozarewa I, Geyer FC, Mackay A, Hakas J, Zvelebil M, Lord CJ, Ashworth A, Thomas M, Stamp G, Larkin J, Reis-Filho JS, Marais R. 2012. Whole genome sequencing of matched primary and metastatic acral melanomas. Genome Research 22:196-207. doi: 10.1101/gr.125591.111. Xia J, Jia P, Hutchinson KE, Dahlman KB, Johnson D, Sosman J, Pao W, Zhao Z. 2014. A meta-analysis of somatic mutations from next generation sequencing of 241 melanomas: a Road Map for the study of genes with Potential clinical relevance. Molecular Cancer Therapeutics 13:1918-1928. doi: 10.1158/1535-7163. MCT-13-0804. 